\title{
UNITED TERRITORIAL COMMUNITY AND PROCESSES OF DECENTRALIZATION IN UKRAINE AND FOREIGN STATES: FEATURES OF CREATION AND FUNCTIONING
}

\author{
Oleksii Yu. Piddubnyi \\ Doctor of Law, Professor, Chairman of the Department \\ of civil and commercial law, Law Faculty, \\ National University of Life and Environmental Sciences of Ukraine \\ 17 Vasylkivska Str., Kyiv, Ukraine, 03040 \\ https://orcid.org/0000-0003-4867-4613 \\ piddubnyi@outlook.com \\ Viktoriia P. Oleksiuk \\ Assistant of the Department of civil and commercial law, Law Faculty, \\ National University of Life and Environmental Sciences of Ukraine \\ 17 Vasylkivska Str., Kyiv, Ukraine, 03040 \\ https://orcid.org/0000-0002-2321-7654 \\ voleksiuk@nubip.edu.ua
}

\begin{abstract}
The article analyzes the peculiarities of the creation and functioning of a united territorial community in Ukraine and foreign countries. It is determined that the reform process in Ukraine at the legislative level is quite fast, but implementation is lagging behind in some places. It is determined that the European Union has a certain influence on the implementation of transformations in Ukraine. In addition, they are all aimed at ensuring the proper depth and pace of decentralization. At the local level, however, there is growing dissatisfaction with the chaos in decentralization and frustration with the lack of promised positive results, although decentralization has been going on for more than seven years.

It is emphasized that in order to prepare the infrastructure, to achieve a real decentralization of power, which is now so much talked about in Ukraine, the neighboring state (which, incidentally, is often equated with Ukraine) Poland, worked long: it took only ten years to develop only decentralization plan. In the countries of "old" Europe, for example in Germany, the reform of local self-government (as a rule, took place within the framework of the reform of the administrative-territorial system) began in the 1960s and in some places continues to this day. However, there are states, of course, that have had several months or weeks to implement decentralization projects.

It is concluded that if we compare the time limits of the formation of UTC in Ukraine and other countries, it is likely that the experience of the Republic of Poland, was used by Ukraine to some extent. Despite the fact that in Ukraine the process of UTC formation is essentially completed, the first elections were held in almost all of them. However, the ability of such
\end{abstract}


UTCs to perform the role and functions defined by Ukrainian law remains unresolved. And in this case, the experience of Latvia, in the form of subsidies from the state budget - would be very appropriate for use in such decentralization processes.

Keywords: united territorial community, decentralization, administrative-territorial system, grants, capacity, international experience.

\section{INTRODUCTION}

The reform process in Ukraine at the legislative level is quite fast, but implementation is lagging behind in some places. While the European Union has some influence on Ukraine's transformation to ensure the proper depth and pace of decentralization, dissatisfaction with the chaos in decentralization and frustration with the lack of promised positive results is growing at the local level, although decentralization has been going on for more than seven years.

In order to prepare the infrastructure, to achieve a real decentralization of power, which is now so much talked about in Ukraine, the neighboring state (which, incidentally, is often equated with Ukraine) Poland, worked long: about ten years took only to develop a decentralization plan. In the countries of „old” Europe, for example in Germany, the reform of local self-government (as a rule, took place within the framework of the reform of the administrative-territorial system) began in the 1960s and in some places continues to this day. However, there are states, of course, that have had several months or weeks to implement decentralization projects.

As the current system of functioning of territorial communities in Ukraine is not perfect and is at the initial stage of its development, studying the experience of foreign countries will allow us to draw some conclusions about the prospects for further development of territorial communities in Ukraine and identify the main directions of implementing best international experience. territorial communities in Ukraine.

The main goal is to identify the best international practices for the development of united territorial communities and determine the directions of their implementation in Ukraine.

\section{METHOD}

The study primarily uses the comparative law method, which allows us to identify some similar and different aspects in the functioning of the united territorial communities of Ukraine and foreign countries.

The topic of decentralization of public power has long been considered by both foreign and domestic scholars, among whom it is worth mentioning M. Ketting, J. Scott, P. John, as well as O. Boryslavska, I. Zaverukha, M. Izha, V. Kubiida, V. Zagorsky, V. Zolotarev T. Kaganovska, A. Kovalenko, V. Kravchenko, V. Kuybida, O. Kuchabsky, A. Lipentsev, V. Mamonova, N. Nyzhnyk, V. Oluyko, L. Pashko, M. Pukhtinsky, A. Reshetnichenko, S. Seryogin, L. Tovazhnyansky. Despite the existence of a regulatory framework and professional developments of Ukrainian and 
foreign scientists, the processes of decentralization and their organizational support remain insufficiently studied.

\section{RESULTS}

According to the draft Strategy for Sustainable Development of Ukraine until 2030, one of the priorities is the further decentralization of power, and hence the further development of united territorial communities (hereinafter - UTC), which is emphasized by the theses set out in the Strategy, strategic vision of sustainable Ukraine's development is based on ensuring national interests and fulfilling international obligations, which includes decentralization and implementation of regional policy, which provides for a harmonious combination of national and regional interests „(Project of Sustainable Development Strategy for Ukraine until 2030, 2020).

To begin with, let us note that the process of creating UTC is a component of the decentralization process both in Ukraine and in other countries of the world.

Thus, the further development of developments in the perfect and effective development of OTG will contribute to the further implementation of the goals of decentralization defined by law.

The main directions in the decentralization reform in Ukraine, already at the present stage of consolidation of administrative-territorial units, are a clear division of powers between the state and various local and regional authorities, as well as informing the public about the decentralization process, including promoting more citizen participation. field decisionmaking.

Dozens of articles and monographs have been written on the importance of the existence of decentralization of power, which define the unconditional advantages of the existence of such a phenomenon. For example, G.M. Shapoval determined that the advantages of decentralization in Ukraine should be:

- decentralized government promotes citizen participation in governance;

- is an element of "civil society” or a bridge that connects civil society with the central state; decentralized government is more responsive to citizens' problems and more able to find solutions that are acceptable to both parties;

- is more efficient and effective in providing services to meet local needs;

- creates a sense of place and community;

- provides opportunities for the development of a new elite;

- is a counterweight to the authoritarian system of the state;

- provides an opportunity to experiment with new structures and policies;

- stimulates competition between regions and communities, etc. (Shapoval, 2019).

It is known that one of the important tools of decentralization of power were UTC, which were created in accordance with the Law of Ukraine „On Voluntary Association of Territorial Communities", which regulates relations arising in the process of voluntary association of territorial communities of villages, towns and cities. also voluntary joining of united territorial communities (On voluntary association of territorial communities, 2015). 
Legislative and executive bodies have been paying close attention to UTC creation processes for a long time. Thus, on June 12, 2020, the Cabinet of Ministers of Ukraine adopted 24 orders on the definition of administrative centers and approval of the territories of communities of regions (Cabinet of Ministers of Ukraine adopted 24 orders on the definition of administrative centers and approval of the territories of regional communities, 2020) As a result, 1,469 territorial communities have been created in Ukraine (including 31 territorial communities in the uncontrolled territory within the Donetsk and Luhansk regions). Therefore, from 1469 only in 1438 of them on October 25, 2020 the first elections of local chairmen of local councils took place.

Thus, it is possible to say that in Ukraine as of April 20211469 OTGs were formed and the process of their formation was completed.

For comparison: in Poland, this process took almost ten years; Hungary - ten months was enough; East Germany - ten weeks, and Czechoslovakia - ten days of the „velvet revolution” (Shapoval, 2019). It is possible to assume that in such processes we were equal to the international experience of the Republic of Poland.

However, creating an UTC is only half the way in decentralization. It is important, first of all, to create affluent communities and, above all, to be financially and economically independent, as stated in several dozen regulations.

Therefore, the future actions of the legislator should be the renewal of the regulatory framework that will be able to provide - the same capacity that so much is said.

It is planned that to continue the reform it is necessary to adopt a number of important laws:

- On the principles of administrative-territorial organization of Ukraine. Within the framework of the current Constitution, it determines the principles on which the administrative-territorial structure of Ukraine should be based, types of settlements, system of administrative-territorial units, powers of state authorities and local selfgovernment bodies on administrative-territorial organization, formation, liquidation, establishment and change. boundaries of administrative-territorial units and settlements, maintaining the State Register of administrative-territorial units and settlements of Ukraine.

- On service in local self-government bodies (new edition), which will ensure equal access to service in local self-government bodies, increase the prestige of service in local selfgovernment bodies, motivate local employees to develop communities and develop themselves.

- Regarding state supervision over the legality of decisions of local self-government bodies.

- About the local referendum.

- Update of laws on local self-government, on local state administrations, etc. (Regarding the further development of the legal framework, 2021)

One of the main aspects of decentralization is the transfer of powers and resources to the level of local governments to meet the social needs of local residents as effectively as possible and to ensure the relationship between residents and the government for quality control and monitoring of local government actions. In this context, fiscal and administrative-political 
decentralization will result in significant non-economic benefits for the development of communities, regions and the state as a whole, including: increased trust in government and accountability of government, increased law-abiding, civil society, and the emergence of training of local political leaders (Kravtsova \& Storonyanska, 2020).

Scholars claim that Ukraine has still failed to create an effective system of local selfgovernment, and the chronic shortage of financial resources of territorial communities and their excessive fragmentation have not allowed to decentralize the budget system of Ukraine. The problem of distribution of powers between the „center” and local communities is exacerbated by the desire of territorial bodies to have additional budgetary resources with a simultaneous lack of experience in performing additional functions (Shapoval, 2019)

Thus, the issue of UTC capacity, despite the fact that a number of Guidelines for the development of capable OTGs have been developed, still remains open and needs to be addressed at the legislative level.

On the other hand, studies of the effects of decentralization are mixed, but in principle confirm the greater positivity of its results for the state and society. The data obtained confirm the positive impact of decentralization on: education, population density, political concentration and the share of services purchased in the private sector. Statistics show that the world's richest countries are more decentralized. Negative effects were identified among the levels of local tax rates, the level of personal income, transfers from the central government, the distance to capital, the regional center and unemployment rates (Ahmad, Bordignon and Brosio, 2016).

It should be noted that almost simultaneously with the process of formation of UTC there was and continues to be a process of consolidation of districts, which in the future involves a kind of organizational and legal change of administrative-territorial units.

It seems important to mention the experience of Latvia, which gradually used both methods of consolidation-stimulation of voluntary amalgamation of municipalities and administrative consolidation. Since the beginning of the reform, four years have been devoted to the formation of voluntary associations of municipalities with their financial incentives by providing a one-time subsidy from the state budget in the amount of $1-5 \%$ of the total municipal budget, after which the next year other municipalities (Shapoval, 2019).

As for such a mechanism in Latvia, it seems quite justified and necessary in the processes of both the formation of OTGs and in the processes of administrative-territorial consolidation, as it has been repeatedly emphasized that the state is obliged to provide subsidies for newly created OTGs in the Ukrainian budget.

Considering the international experience of UTC functioning in foreign countries of the world, I would like to mention the problem that arises in the process of decentralization, which is the choice between equality and hierarchy. For example, the French constitution enshrines the principle that no local authority can exercise power or supervise other authorities in relations between different regional and local institutions, but in reality this is more a formality than a practice. Instead, in the German legal field, the priority is the hierarchy of relations between different levels of government: legislation adopted by land authorities, binding on local governments located in their territories, and a higher level of 
regional authorities: (local) authorities have the right to exercise supervision of the activities of the lower (Zabeyvorota, 2014).

In this case, it is impossible to form an unambiguous position for the Ukrainian legislation, although such a practice really confirms the importance and would increase the credibility of the newly created UTCs.

The Analytical Note contains the thesis that based on the implementation of the first steps of the decentralization process in Ukraine, taking into account international experience and domestic realities, the development of urban settlements and villages around large cities by providing jobs for young people is proposed to address the financial capacity of local communities. infrastructure development, promotion of investments for the implementation of promising innovative projects, which will increase their competitiveness, and thus financial capacity (Analytical note...).

Zabeyvorota T.V., researching the international experience of UTC creation and decentralization processes, determined the following prospects for its implementation in Ukraine. Among which highlights:

- wide consideration of the opinion of the population, which establishes the need for local referendums, opinion polls not only during the transformation, but also when developing the concept of reform, involving the public, local government representatives in special bodies for the development and implementation of reform;

- gradualness, which requires careful preparation, provision and development of infrastructure. study of the state of administrative territories;

- establishing criteria for the creation of new administrative-territorial units without specifying quantitative and qualitative characteristics, the possibility of applying an individual approach to decisions. of each region.

- possibility to choose the method of consolidation: unification of municipalities or establishment of inter-municipal cooperation (Zabeyvorota, 2014).

Sharing the opinion of the scientist, we can say that modern development of UTC, although at a slow pace of its development, in some way corresponds to those countries whose experience shows significant results in decentralization processes. However, in terms of UTC capacity, they are inferior to the highly developed countries of the world, and therefore the role of the state in the first stage of UTC creation should be significantly higher than it is now.

\section{CONCLUSIONS}

Thus, based on the analysis of the processes of UTC creation and in general the process of decentralization in Ukraine and foreign countries, we can emphasize the certainly important role of borrowing international experience for Ukraine. If we compare the time limits of UTC information in Ukraine and other countries, it is quite probable that the experience of the Republic of Poland was used by Ukraine to some extent. Despite the fact that in Ukraine the process of UTC formation is essentially completed, the first elections were held in almost all of them. However, the ability of such UTCs to perform the role and functions defined by Ukrainian law remains unresolved. And in this case, the experience of Latvia, in the form of 
subsidies from the state budget would be very appropriate for use in such decentralization processes.

\section{REFERENCES}

Sustainable Development Strategy for Ukraine until 2030. Draft Law of Ukraine № 9015 (2018, august 7). Retrieved from http://w1.c1.rada.gov.ua/pls/zweb2/webproc4_1?pf3511=64508

Shapoval V.G. (2019). Analysis of international experience in the development of territorial communities. The current state of research and technology in industry, 2 (8), 5-14. Retrieved from https://doi. org/10.30837/2522-9818.2019.8.005.

On voluntary association of territorial communities. № 157-VIII (2015, May 14). Retrieved from https:// zakon.rada.gov.ua/laws/show/157-19\#Text

On June 2, 2020, the Cabinet of Ministers of Ukraine adopted 24 orders on the definition of administrative centers and approval of the territories of regional communities. (2020). Retrieved from https://

decentralization.gov.ua/newgromada

Regarding the further development of the legal framework. (2021). Retrieved from: https:// decentralization.gov.ua/about

Kravtsova V.S. \& Storonyanska I. Z. (2020). Territorial communities in the conditions of decentralization: risks and mechanisms of development (Series „Problems of regional development”). Lviv.

Ahmad, E, Bordignon, M. and Brosio, G. (2016). Multi-level finance and the Euro crisis. Causes and Effects, Edward Elgar Publishing, Cheltenham, UK and Northampton, MA, USA.

Vasilyuk, O. (2017). Capacity building of united territorial communities: personnel aspect. efficiency of public administration, 2 (51), 1.

Zabeyvorota T.V. (2014). Foreign experience in implementing administrative-territorial reform in the context of decentralization of power. Foreign policy and national security, 3 (46).

Analytical note: Agglomerations, international experience, trends, conclusions for Ukraine. (2017). Retrieved from https://www.csi.org.ua/books/aglomeratsiyi-mizhnarodnyj-dosvid-tendentsiyi-vysnovkydlya-ukrayiny-analitychna-zapyska/ 